УдК 343.224

\author{
P. I. Благута, О. М. Процюк
}

\title{
ВИВЧЕННЯ ОСОБИ НЕПОВНОЛІТНЬОГО ПІДОЗРЮВАНОГО ТА НАПРЯМИ ВИКОРИСТАННЯ ОТРИМАНОЇ ІНФОРМАЦІЇ ПІД ЧАС ПРОВЕДЕННЯ ДОПИТУ
}

Постановка проблеми. У теорії кримінального процесу та в практичній діяльності слідчих підрозділів існує чимало проблемних аспектів, що стосуються допиту неповнолітніх підозрюваних. Складність його проведення зумовлена специфікою психології формування такої категорії допитуваних, їхніми віковими й індивідуальними особливостями. Слідчим необхідно вміти діагностувати психологічні характеристики неповнолітніх підозрюваних та використовувати їх у різноманітних напрямах організації допиту.

Мета статті - розкрити взаємозв'язок основних елементів вивчення особи неповнолітнього підозрюваного та вплив їх на ефективність допиту як слідчої (розшукової) дії загалом. Відповідно, в роботі зосереджена увага на виконанні таких основних завдань: з'ясувати, що означає дослідження особи неповнолітнього; визначити основні методи дослідження особи допитуваного та напрями використання отриманої інформації під час проведення допиту неповнолітнього підозрюваного.

Аналіз останніх досліджень і публікацій. Вагомий внесок у розроблення наукових засад проведення допиту зробили такі відомі вчені-процесуалісти, як Ю.П. Аленін, В.І. Галаган, І.В. Гловюк, А.О. Ляш, О.Р. Михайленко, В.Т. Нор, М.А. Погорецький, В.О. Попелюшко, Л.Д. Удалова, М.О. Янковий та ін. Проблематику розслідування правопорушень, тактику окремих слідчих (розшукових) дій розкрито в роботах криміналістів В.П. Бахіна, В.Д. Берназа, П.Д. Біленчука, В.К. Весельського, В.Я. Горбачевського, А.В. Іщенка, В.О. Коновалової, В.С. Кузьмічова, В.Г. Лукашевича, Є.Д. Лук'янчикова, В.М. Тертишника, С.В. Харченка, К.О. Чаплинського, С.С. Чернявського, Ю.М. Чорноус, В.Ю. Шепітька. Психологічні особливості проведення слідчих дій, зокрема за участю неповнолітніх, також досліджували В.Л. Васильєв, А.П. Венедиктов, Н.І. Гаврилова, Н.В. Грищенко, М.Є. Дирдін, Д.В. Затенацький, М.В. Костицький, Д.В. Куриленко, I.В. Озерський, Н.В. Павлюк, С.А. Риб'янець, Ю.А. Чаплинська та ін.

Різні аспекти проведення допиту розглядали й інші вчені, зокрема Н.I. Гуковська, А.В. Дулов, С.П. Єфімічев, М.І. Кулагін, І.А. Макаренко, 
Г.М. Міньковський, П.Д. Нестеренко, Л.Е. Орбан-Лембрик, М.І. Порубов, Є.В. Стрельцова, С.В. Тетюєв, О.Ю. Ямпольський.

Водночас, незважаючи на наявність змістовних наукових досліджень, що мають практичну спрямованість, мало зосереджується увага на тому, яким чином отримана інформація про особистість неповнолітнього підозрюваного в ході його дослідження слідчим впливає на встановлення психологічного контакту з допитуваним та на вибір методів психологічного впливу і тактичних прийомів.

Виклад основного матеріалу дослідження. Для успішного проведення допиту слідчому необхідно підготуватися до нього. Одним із головних завдань слідчого є створення інформаційної бази допиту. Підготовка до допиту розпочинається з вивчення наявних матеріалів кримінального провадження. Зазвичай у початкових матеріалах недостатньо інформації, що характеризує особу підозрюваного. Матеріали здебільшого висвітлюють обставини вчиненого правопорушення і коло учасників [2, с. 85]. Важливим складником інформаційної бази допиту є вивчення особи допитуваного. Ознайомлення з особистістю допитуваного дозволяє слідчому правильно визначити послідовність постановки питань, передбачити реакцію на них допитуваного, завчасно визначити методи впливу на останнього $[4$, с. 64$]$.

Крім загальних обставин, які підлягають доказуванню у кримінальному провадженні, під час досудового розслідування кримінальних правопорушень, учинених неповнолітніми, також з'ясовуються повні й усебічні відомості про особу неповнолітнього: його вік, стан здоров'я та рівень розвитку, інші соціально-психологічні риси особи, які необхідно враховувати під час індивідуалізації відповідальності чи обрання заходу виховного характеру. За наявності даних про розумову відсталість неповнолітнього, не пов'язану з психічною хворобою, має бути з'ясовано, чи міг він повністю усвідомлювати значення своїх дій і якою мірою міг керувати ними; ставлення неповнолітнього до вчиненого ним діяння; умови життя і виховання неповнолітнього; наявність дорослих підбурювачів та інших учасників кримінального правопорушення [8, с. 39, 187 ].

Під вивченням особистості підозрюваного розуміється цілеспрямована діяльність слідчого із встановлення певної сукупності даних, що характеризують підозрюваного і мають значення для правильного застосування норм кримінального закону, точного дотримання приписів кримінального процесуального законодавства, вибору і використання найефективніших прийомів під час проведення окремих слідчих дій. Криміналістичний аспект вивчення допитуваного передбачає отримання про нього такої інформації, яка може бути використана для вибору найбільш ефективних у конкретному випадку тактичних прийомів допиту, а психологічний аспект - для вибору найбільш ефективного способу впливу на допитуваного. Вивчення особистості має бути спрямовано на отримання такої інформації, за допомогою якої можна було б прогнозувати поведінку цієї особи [13, с. 112-113; 9, с. 33]. Результати допиту значною мірою визначаються тим, наскільки 
повно вивчена особистість допитуваного, наскільки показання, отримані в процесі такого вивчення, правильно використані для вибору найбільш ефективних прийомів і засобів вирішення тактичних завдань розслідування. Саме тому основним елементом підготовки до допиту є вивчення особистості, яку необхідно допитати.

Основними методами вивчення особистості допитуваного є: а) спостереження за допитуваним як під час допиту, так і в процесі інших слідчих дій; б) бесіда; в) виокремлення показань про допитуваного 3 показань інших осіб, довідок, характеристик, записів у щоденниках тощо [5, с. 30].

Під спостереженням розуміють спеціально організоване, систематичне, навмисне та цілеспрямоване сприйняття особистості 3 метою вивчення різноманітних виявів їі психіки. Від простого сприйняття спостереження відрізняється своєю навмисністю, цілеспрямованістю, планомірністю, тому процес спостереження завжди пов'язаний із концентрацією уваги на об’єкті спостереження, що підсилює сприйнятливість спостерігача. Дані, отримані в результаті спостереження, мають значення для побудови правильної тактики допиту [13, с. 118-123]. ВО. Коновалова зазначає, що спостереження, уживане для діагностики психологічного статусу особи типу темпераменту (реакція на подразник), рис характеру особи, охоплює такі показники, що включають поведінку особи в умовах початку допиту. Оскільки матеріал для спостереження, який виражається у зовнішніх виявах особи, надзвичайно обмежений, то і результати його завжди мають попередній, орієнтувальний характер. Цей метод має на меті виявлення певних рис характеру й ознак темпераменту, що свідчить про психологічне обличчя допитуваного. Спостереження охоплює манери допитуваного, його комунікабельність (на початку допиту), реакцію на подразник (поставлені питання), психічний стан, спричинений процесуальним становищем і метою запрошення до слідчого. Під час оцінки результатів спостереження не варто забувати, що особа, за якою здійснюють спостереження, перебуває у незвичній для неї обстановці і мікросередовищі, де вона виражає більш вільно і безпосередньо свої вияви та вчинки. У новій обстановці, у якій допитуваний усвідомлює свою роль і процесуальне становище, він стримує свої вияви, часто надає своїй поведінці обрані роль і форму [7, с. 89].

Для діагностики особи допитуваного можна використовувати і метод бесіди. Бесіду розуміють як джерело і як спосіб пізнання психологічних явищ у процесі мовного спілкування. Цей метод дає можливість отримати показання безпосередньо від їх власників, дозволяє отримувати інформацію цілеспрямовано, впливати на їі повноту, уточнювати і конкретизувати у процесі бесіди окремі обставини. Мету бесіди може бути досягнуто лише в тому разі, коли слідчому вдасться встановити контакт із допитуваним і вдало вибрати момент для їі проведення [13, с. 118-123].

Поряд із названими методами для діагностики допитуваного може використовуватися метод узагальнення незалежних характеристик, який полягає в узагальненні щонайбільшого обсягу відомостей про досліджувану особистість у різний час і в різноманітних видах діяльності. Характеристи- 
ки можуть бути усними і письмовими, вони можуть грунтуватися на тривалих, багаторічних спостереженнях або ж можуть скластися на основі одноразового, але яскравого моменту під час випадкової зустрічі.

Отримати інформацію про допитуваного можна також, аналізуючи матеріали кримінального провадження, під час проведення інших слідчих дій шляхом спеціального збору відомостей із місця навчання у формі характеристик [13, с. 118-123]. Цей метод передбачає збирання відомостей про допитуваного в осіб, які мали з ним різні соціальні взаємини. Збирання відомостей про особу допитуваного відповідно до рекомендацій криміналістики передбачає з'ясування комплексу даних, які широко використовуються і для установлення психологічного контакту, і для обрання тактичних засобів допиту, і для оцінки інформації, яку буде отримано від цієї особи.

Застосування вказаних методів ізольовано або у взаємозв'язку дозволяє діагностувати психологічні характеристики особи і використовувати їх у різноманітних напрямах організації допиту, а саме: в установленні психологічного контакту; у визначенні системи тактичних засобів допиту; у визначенні характеру і виду можливого та найбільш ефективного психологічного впливу; в оцінці отриманої інформації. Психологічна діагностика особи передбачає не абстрактне дослідження компонентів такої характеристики тільки вказаними методами, а й оцінку динаміки психологічних процесів, які виявляються під час провадження допиту на всіх його етапах. У процесі допиту залежно від його психічної напруженості (актуалізація запам'ятованого, виявлення неправдивих показань, викриття у вчиненні злочину) характер психічних виявів особи може бути різним. Тому в оцінці психологічної діагностики надзвичайно важливо встановити, які подразники найбільш ефективні, стимулюють особу до давання показань, а які, навпаки, діють негативно або нейтрально в аспекті одержання інформації [7, с. 90].

Спостерігаючи за діями неповнолітнього підозрюваного та манерою спілкування його з батьками, захисником, можна попередньо встановити, чи не готується дитина «зіграти» заздалегідь вивчену роль. Після початку допиту, використовуючи метод бесіди, слідчий, зокрема, має можливість перевірити отриману у процесі спостереження невербальну інформацію від неповнолітнього підозрюваного. Для цього, ставлячи запитання, слідчий плавно переходить до допиту. Встановивши психологічний контакт із допитуваним, слідчий може провести допит у формі бесіди, що буде для підлітка лише позитивним. Метод узагальнення незалежних характеристик дозволить слідчому отримати інформацію, яку він не міг отримати від самого допитуваного, використовуючи методи спостереження і бесіди. Причиною цього могло бути бажання допитуваного приховати певну інформацію, що характеризує його негативно, або ж подати негативну інформацію про себе в іншому аспекті, створивши таким чином ілюзію позитивної його характеристики. Отже, для вивчення особистості неповнолітнього підозрюваного слідчому необхідно, на нашу думку, використовувати в поєднанні всі зазначені методи для повного й усебічного вивчення особи допитуваного. 
Вивчаючи особистість допитуваного, слідчий виявляє соціальний статус цієї особи, її соціальні ролі, соціальні позитивні і соціальні негативні особистісні якості, за можливості з'ясовує тип темпераменту. Як зазначає Г.Г. Доспулов, темперамент - це відносно стійка характеристика особи з боку динаміки, тонусу й урівноваженості ії психічної діяльності. За темпераментом слідчий може скласти уявлення про врівноваженість підозрюваного, ступінь його реакції на вплив, ступінь рухливості чи інертності в діяльності, ступінь замкнутості чи товариськості [3, с. 88]. А.Н. Васильєв і Л.М. Карнєєва констатують, що практичне значення віднесення допитуваного до того чи іншого типу вищої нервової системи (темпераменту) полягає у тому, що можна зробити висновки про те, як може ця особа поводити себе під час вчинення злочину, чи в змозі вона правильно сприйняти його та запам'ятати, як може ставитися до події злочину надалі, якої позиції буде дотримуватися під час допиту, який тактичний прийом доцільно вибрати для встановлення психологічного контакту й отримання від неї правдивих показань [1, с. 12]. Н.Ш. Сафін акцентує увагу на тому, що важливо знати темперамент, риси характеру допитуваного для встановлення із ним контакту, правильного розуміння особливостей його поведінки, отримання можливості варіювання відповідним чином тактичними прийомами допиту [15, с. 67].

Усе це необхідно враховувати під час підготовки до допиту та його планування, оскільки холерики і меланхоліки більш запальні, категоричніші у своїх судженнях, імпульсивні. Флегматики спокійні, витривалі, але й більш ригідні, стандартні у своїх судженнях, оцінках, у виборі тактичної лінії поведінки. Сангвініки вирізняються нервовою витривалістю, стійкістю настрою. Під час допиту сильних і рухливих типів (холерики і сангвініки) темп, ритм і напруженість допиту може бути досить високим, вступна частина допиту може бути скорочена до необхідного мінімуму, перехід від однієї теми до іншої можна здійснювати без попередньої підготовки. Під час допиту сильних, урівноважених, інертних типів (флегматик) необхідно враховувати такі динамічні характеристики, як повільність у поєднанні із силою нервових процесів. У такої особи порівняно тривалий період «втягування». Тому динаміку допиту флегматика характеризує відносно тривала вступна частина, повільний перехід від висвітлення одного епізоду до іншого, порівняно вповільнений ритм розмови. Особливого підходу під час допиту потребують слабкі типи. Необхідно пам'ятати, що слабкість нервової системи зазвичай поєднується із високою чутливістю, саме тому меланхоліки значно «тонше» від інших типів реагують на похвалу або осуд їхніх дій. Однією із характерних реакцій цього типу на різні життєві труднощі є схильність до «ступору». За дуже високих ритмів напруженості допиту в меланхоліка може виникнути стан в'ялості та апатії [10, с. 92].

Слідчому необхідно пам'ятати, що поведінка неповнолітніх відрізняється низкою особливостей - недостатністю життєвого досвіду і пов'язаним із цим низьким рівнем самокритичності, відсутністю усебічної оцінки життєвих обставин, підвищеною емоційною збудливістю, імпульсивністю, 
руховою і вербальною активністю, навіюваністю, загостреним відчуттям незалежності, прагненням до престижу, негативізмом, неврівноваженістю. Зазначені знання допомагають слідчому не лише в отриманні повної та об’єктивної інформації про розслідувану подію, що міститься у показаннях неповнолітнього, а й в оцінці достовірності цього джерела доказів. У результаті виникає необхідність постановки питання про підвищення вимог до матеріалів, які збираються.

Особливості вивчення даних про особистість допитуваного полягають у ймовірному характері отриманої інформації. Більшість висновків щодо характеристики особистості допитуваного приблизні, оскільки інформація, що лежить у ї основі, зумовлена цілим комплексом причин поведінки тієї чи іншої особи, які не завжди можна встановити. Тому всі отримані дані про особистість неповнолітнього допитуваного слід розглядати лише як гіпотези для подальшої перевірки [9, с. 34].

Вивчаючи особу неповнолітнього підозрюваного, слідчий акцентує увагу на індивідуальних особливостях психіки. Дитяча психіка тісно пов'язана з особливостями домашнього виховання, поведінкою підлітка в побуті, а також поведінкою та ставленням до нього батьків. До вікових особливостей психіки дітей перехідного віку належить схильність до фантазування, про що завжди повинен пам'ятати слідчий під час оцінки результатів слідчих дій за участю неповнолітніх. Їхнє емоційне життя досить нестійке, що можна пояснити тимчасовою дисгармонією між функціями кори і підкірки головного мозку, першої і другої сигнальних систем, що характерно для періоду статевого дозрівання. Часто підлітки сприймають багато подій неповністю та неточно, але в них у пам'яті дуже часто залишаються такі деталі, на які дорослі навіть не звертають уваги.

Також слідчому необхідно, вивчаючи особу неповнолітнього підозрюваного, враховувати і статеві особливості психології неповнолітніх. Загальна тенденція гендерних відмінностей у сформованості сенсу життєвих орієнтацій у неповнолітніх підозрюваних стосується такого. Достовірно більше юнаків, ніж дівчат характеризуються низьким рівнем осмисленості життя (78\% проти $32 \%$ ). Дівчата порівняно з юнаками відрізняються переважно середнім рівнем осмисленості життя. Юнаки частіше за дівчат вважають, що події у житті не підвладні свідомому контролю. Дівчата ж частіше оцінюють себе як здатних побудувати життя відповідно до своїх цілей та уявлень. Удвічі більше дівчат, ніж юнаків (66\% проти $31 \%$ ) вважають, що людина може контролювати своє життя, приймати рішення та втілювати ї. Низьким локусом контролю життя відрізняються $30 \%$ дівчат та $66 \%$ юнаків. Спрямованість дівчат на майбутнє зумовлює відмінності у ставленні до процесу життя, тобто до сучасності. Дівчата вище, ніж юнаки оцінюють наповненість смислом сучасного, частіше осмислюють перебування у місцях позбавлення волі, розцінюють цей період як перехідний, черпають у майбутній реалізації життєвих цілей смисл для існування у теперішньому.

Дівчата, на відміну від юнаків, надають достовірно більший особистісний смисл як позитивним, так і негативним подіям власного життя, при 
цьому більшою мірою схильні вчитися на помилках минулого та бачать більше позитивного смислу в майбутньому.

Смислова сфера особистості дівчат - неповнолітніх підозрюваних забарвлена більшим, ніж у юнаків прагненням до переживань гострих відчуттів і потенціальною готовністю інтерпретувати будь-яку життєву ситуацію як конфліктну. Як у юнаків, так і у дівчат - неповнолітніх правопорушників у структурі прагнення до стимуляції найбільше виражена потреба в пошуках гострих відчуттів. Причому в дівчат вона достовірно вища, ніж у юнаків, що робить дівчат значно більше схильними до надзвичайних пригод. Крім того, дівчатам достовірно більш властиве неадаптивне прагнення до труднощів, ніж юнакам. Не було виявлено значимих відмінностей між юнаками та дівчатами за такими шкалами, як нестерпність одноманітності та пошук нових вражень.

Дівчата - неповнолітні підозрювані бачать смисл життя у тому, щоб переживати нові відчуття та будувати життя відповідно до своїх цінностей, головними з яких є звільнення із місць позбавлення волі та самореалізація щодо досягнення матеріального благополуччя, створення сім’і і виховання дітей $[11$, с. 7$]$.

Існують і такі індивідуально-психологічні особливості, які призводять до ускладнень у свідомій регуляції поведінки, а саме: своєрідна емоційна вразливість дівчат, що виявляється у посиленій чутливості до несприятливих впливів однолітків і в міжособистісних стосунках із батьками зокрема; імпульсивність та агресивність, утілення будь-яких мотивів у конкретні вчинки та дії, зокрема й протиправні; неадекватність прагнень, які виявляються у нестримному тяжінні до здійснення бажання, що може призвести до брехливості, крадіжок, наркоманії; тип акцентуації характеру в дівчат може виявлятись у демонстративності поведінки, підкресленні свого «Я», постійному намаганні бути у центрі уваги, тяги до лідерства чи, навпаки; у надмірній піддатливості під чужий вплив, нестійкості в поведінці, думках [16, c. 33].

Особистість неповнолітнього підозрюваного має деякі специфічні риси, що у своїй сукупності постають як психологічна основа протиправних дій. Для неповнолітніх нерідко характерна сугестивність, надмірна довірливість, схильність до наслідування. Також характерні підвищена активність, рухливість, ініціативність, надлишок енергії, викликаний загальним підйомом життедіяльності, ростом життєвих сил. Неповнолітні особливо бажають активної діяльності, незвичних пригод, гостро конфліктних ситуацій. Підлітки мають схильність до впертості, роздратованості, супротиву, критичності, агресивності, ненависті, ізоляції, байдужості. Основним коренем упертості є бажання звільнення, сильна потреба у свободі й самостійності. Підліток внутрішньо віддаляється від батьків, стає байдужим до сімейного і шкільного життя. Отже, важливе місце серед вікових особливостей підлітка посідають негативізм, потреба у престижі, свободі та самостійності.

Із метою уникнення помилок у роботі з підлітками необхідно добре знати природу фізіологічних процесів, що відбуваються в організмі підлітка, 
для унеможливлення перевантажень. За нормальних умов між силою подразника і реакцією на нього нервової системи існує певна залежність, яка має вікові й індивідуальні особливості. У підлітковому віці ці співвідношення порушуються, що пов'язано із збудженим станом центральної нервової системи. Через це, наприклад, і сильні, і слабкі подразники можуть викликати однакову за силою реакції відповідь. Може бути й по-іншому: сильні подразники взагалі не викликають відповіді, а на слабкі відповідь є. Річ у тім, що центральна нервова система підлітка стає тимчасово нездатною до відповіді на сильний подразник, оскільки він остаточно розбуджує іiі і переводить у стан гальмування, тому немає реакції. Слабкий же подразник не викликає цього, тому на нього реакція зберігається. Може бути й такий стан центральної нервової системи, коли подразник узагалі викликає несподівану, неадекватну реакцію. Характерно, що в дівчаток більшою мірою виражено порушення емоційного плану - підвищена образливість, плаксивість, безпричинна зміна настрою, у хлопчиків - зміна поведінки і реакцій руху. Їхні дії супроводжуються супутніми рухами рук, ніг, тулуба (не можуть сидіти спокійно, щось крутять у руках, чіпають щось) [12].

На становлення інтересів також суттєво впливають статеві відмінності. У хлопчиків негативний етап протесту проти дитячого типу стосунків настає пізніше, ніж у дівчаток (через пізніше статеве дозрівання і соціальне дорослішання), але відбувається бурхливіше і триває довше, а негативізм (дії, які суперечать вимогам оточуючих) виражений сильніше [14, с. 213].

Отже, підлітковому віку властиві емоційна збудженість, деяка неврівноваженість, швидкі зміни настрою і форм поведінки. Ці особливості характеру пов'язані з підвищеною імпульсивністю, відносно низьким ступенем свідомого контролю [6, с. 20-22]. Дівчаткам, зокрема, більше притаманні контроль за власним життям, оцінка наповненості смислом сучасного, схильність учитися на помилках минулого, бажання переживати нові відчуття та будувати життя відповідно до своїх цінностей. Дівчата також характеризуються своєрідною емоційною вразливістю (що виявляється у формі підвищеної образливості, плаксивості, безпричинній зміні настрою), неадекватністю прагнень, вимогами свободи, прагненням звільнитися від контролю батьків, прагненням автономії. Хлопці характеризуються низьким рівнем осмисленості життя, переконанням у тому, що події у житті не підвладні свідомому контролю, низьким локусом контролю життя, схильністю до ризику та небезпеки. Порушення емоційного плану в них виражаються, на відміну від дівчаток, у зміні поведінки та реакцій руху. Ці статеві особливості необхідно враховувати слідчому під час проведення допиту неповнолітніх підозрюваних, зокрема у процесі встановлення психологічного контакту та застосування тактичних прийомів.

Висновки. Отже, дослідження особи неповнолітнього підозрюваного передбачає виявлення соціального статусу неповнолітнього; діагностику зовнішніх виявів особи допитуваного (агресивність, неврівноваженість, товариськість чи замкнутість); визначення його темпераменту, що впливає на темп і ритм проведення допиту; з'ясування особливостей психіки не- 
повнолітніх (емоційна збудженість, схильність до наслідування та навіювання тощо), гендерних відмінностей та особливостей емоційних реакцій перехідного віку, що пояснюються гормональними і фізіологічними процесами (дівчата характеризуються плаксивістю, частою зміною настрою, образливістю, хлопці - раптовою зміною поведінки і реакцій руху). Вивчення особи неповнолітнього підозрюваного є основою підготовки до допиту, який здійснюється за допомогою методів спостереження, бесіди та узагальнення незалежних характеристик. Застосування указаних методів у взаємозв'язку дає змогу діагностувати психологічні характеристики особи і використовувати ї у різноманітних напрямах організації допиту, а саме: під час установлення психологічного контакту, у визначенні найефективніших методів психологічного впливу й тактичних прийомів допиту, в оцінці отриманої інформації.

\section{Література}

1. Васильев А.Н.Тактика допроса при расследовании преступлений / А.Н. Васильев, Л.М. Карнеева. - М., 1970. - 208 с.

2. Гуковськая Н.И. Расследование и судебное разбирательство дел о преступлениях несовершеннолетних / Н.И. Гуковськая, А.И. Долгова, Г.М. Миньковский. - М. : Юрид. лит-ра, 1974. -208 с.

3. Доспулов Г.Г. Психология допроса на предварительном следствии / Г.Г. Доспулов. М. : Юрид. лит-ра, 1976. - 112 с.

4. Дулов А.В. Тактика следственных действий / А.В. Дулов, П.Д. Нестеренко. - Минск : Вышэйш. шк., 1971. - 272 с.

5. Ефимичев С.П. Допрос : [учеб. пособ.] / С.П. Ефимичев, Н.И. Кулагин, А.Е. Ямпольский. - Волгоград, 1978. - 48 с.

6. Каневский Л.Л. Расследование и профилактика преступлений несовершеннолетних / Л.Л. Каневский. - М. : Юрид. лит-ра, 1982. - 112 с.

7. Коновалова В.О. Правова психологія : [навч. посіб.] / В.О. Коновалова. - Харків : Основа, 1996. - 184 с.

8. Кримінальний процесуальний кодекс України. - К. : Центр учб. літ-ри, 2012. - 254 с.

9. Лукашевич В.Г. Тактика общения следователя с участниками отдельных следственных действий : [учеб. пособ.] / В.Г. Лукашевич. - К. : НИиРИО КВШ МВД СССР им. Ф.Э. Дзержинского, 1989. - 88 с.

10. Мостова І.М. Юридична психологія / І.М. Мостова. - К. : ВІРА-P, 1999. - 120 с.

11. Мушинська О.В. Гендерні особливості смислової сфери особистості неповнолітніх правопорушників : автореф. дис. ... канд. психол. наук : спец. 19.00.06 «Юридична психологія» / О.В. Мушинська ; Нац. ун-т внутр. справ. - Харків, 2005. - 19 с.

12. Особливості психології підлітків [Електронний ресурс]. - Режим доступу : http: / / osvita.ua/vnz/reports/psychology/10068/.

13. Порубов Н.И. Допрос: процессуальные и криминалистические аспекты : [монография] / Н.И. Порубов, А.Н. Порубов. - М. : Юрлитинформ, 2013. - 304 с.

14. Савчин М.В. Вікова психологія : [навч. посіб.] / М.В. Савчин, Л.П. Василенко. - К. : Академвидав, 2005. - 360 с.

15. Сафин Н.Ш. Допрос несовершеннолетнего подозреваемого в советском уголовном судопроизводстве (процессуальный и криминалистический аспекты проблемы) / Н.Ш. Сафин. Казань : Изд-во Казан. ун-та, 1990. - 160 с.

16. Шевченко Л.О. Соціально-психологічні чинники, які зумовлюють антисуспільну поведінку підлітків / Л.О. Шевченко / / Актуальні проблеми профілактики злочинності та правопорушень серед неповнолітніх : матер. наук.-практ. конф. (м. Львів, 22-23 листоп. 2002 р.). Львів : ЛІВС при НАВС України, 2004. - 300 с. - С. 29-34. 


\section{Ано т а ц і я}

Благута P. I., Процюк О. М. Вивчення особи неповнолітнього підозрюваного та напрями використання отриманої інформації під час проведення допиту. - Стаття.

У ході дослідження з'ясовано, що таке вивчення особи неповнолітнього, визначено основні методи дослідження особи допитуваного та окреслено напрями використання отриманої інформації під час допиту неповнолітнього підозрюваного.

Ключові слова: неповнолітній підозрюваний, метод дослідження особи, спостереження, бесіда, психологічний вплив.

\section{Анн н т а ци я}

Благута Р. И., Процюк О. Н. Изучение личности несовершеннолетнего подозреваемого и направления использования полученной информации во время допроса. Статья.

В ходе исследования установлено, что представляет собой исследование личности несовершеннолетнего, определены основные методы исследования личности допрашиваемого и обозначены направления использования полученной информации во время допроса несовершеннолетнего подозреваемого.

Ключевые слова: несовершеннолетний подозреваемый, метод исследования личности, наблюдение, беседа, психологическое воздействие.

\section{S u m m a r y}

Blahuta R. I., Protsiuk O. M. The study of the personality of a minor suspect and the direction of using the information obtained during interrogation. - Article.

The study found that a person is a minor research, the main methods outlined persons questioned and uses of the information received during interrogation of a minor suspect.

Key words: juvenile suspect, method of investigation person, observation, interview, psychological impact. 